\title{
SPECIAL ASPECTS OF THE MODERN WORLD ECONOMY: TRANSITION FROM A UNIPOLAR TO A MULTIPOLAR WORLD SYSTEM
}

\author{
Irina V. Minakova ${ }^{1}$, Tatyana N. Bukreeva ${ }^{2}$, Olga I. Solodukhina ${ }^{3}$, Olga G. Timofeeva ${ }^{4}$
}

\begin{abstract}
This paper reveals the consequences of the unipolar system of the world economy provided by the United States leadership in the military-technological, financial-economic, geopolitical and information-ideological spheres. It was established that after the collapse of the socialist camp, the concepts of 'humanitarian intervention' and 'spreading democracy' were brought to the forefront. In practice, Western European countries have demonstrated their readiness to judge the solutions of domestic political disputes in other countries of the world, especially when it comes to geopolitically important countries. A series of 'colour revolutions' have become a demonstration of this policy. Therefore, the globalization of the modern world does not mean the homogenization of development indicators of countries', but instead leads to further delamination and inequality. The gap between the world leaders and the rest of the world in terms of indicators reflecting the dynamics of the standard of living, the quality of life, scientific and technological progress, after the collapse of the Soviet Union, has significantly increased.

It is illustrated that attempts of the US to consolidate its hegemony in the form of 'leadership' in the world had led to the erosion of international legal principles enshrined in the United Nations Charter. Therefore, the United States attempts to solve the problems in Iraq and Afghanistan unilaterally has failed.The objective and subjective signs of a global restructuring of the existing unipolar world system are revealed.
\end{abstract}

JEL Classification: F01, F02; DOI: http://dx.doi.org/10.12955/cbup.v6.1182

Keywords: unipolar world, international relations, world economic, global management.

\section{Introduction}

The modern world economy can be described as unipolar. Unipolarity is characterised as a structure of the world with a single pole of world power, which significantly exceeds the potential of its closest competitors. After the collapse of the Soviet Union, the role of a pole of the world was played by the United States of America. The result of a unipolar world was an increasing inequality between countries. So, from the moment of the collapse of the socialist system, income inequality, or the gap between the richest and poorest groups has been growing markedly. According to the report on human development of 2013, many African countries are balancing on the verge of mass starvation. In Guinea, one out of every five children under five years of age, and in Madagascar every third child is underweight. In the fifteen-year period after the collapse of the USSR, the death toll in one thousand children increased in Zimbabwe by $38.2 \%$, Swaziland by $49.1 \%$ and Botswana by $113.8 \%$.

The quality and volume of educational services provided differ fundamentally in the regions of the world. About 800 million people over 15 years of age remain illiterate - $18 \%$ of the world's adult population. 76 countries of the modern world do not provide legal guarantees of free primary education.

In some countries, the majority of the adult population is illiterate. According to a special study by UNESCO, in 30 out of 91 countries more than a quarter of school children are unable to complete the fifth grade. The country gap in life expectancy is growing. The gap between Japan with the highest in the world life expectancy and Afghanistan with low life expectancy indicators is twofold. In many countries the average age limit does not exceed 20 years old.

The above mentioned figures support the hypothesis that the world is entering a degradation phase. This means that the problem of changing world order model is very relevant. A new world-order should be opposed to a unipolar model of the world.

The purpose of the research is to study the essential prerequisites for the transformation of the modern model of the world economy.

\footnotetext{
${ }^{1}$ Faculty of International Relations and Public Administration, Southwest State University, minakovairena@yandex.ru

${ }^{2}$ Faculty of International Relations and Public Administration, Southwest State University, tnbinchina@yandex.ru

${ }^{3}$ Faculty of International Relations and Public Administration, Southwest State University

${ }^{4}$ Faculty of International Relations and Public Administration, Southwest State University
} 


\section{Analysis of the main publications}

The theory of a multipolar world was developed in the papers of Kissinger H. (1994, 2009), Brzezinski Zb. (2009), Waltz K.C. (2000, 1993), Huntington S. (1999, 1993), Kegley Ch.W., Raymond G. (1994).

During the global financial and economic crisis of 2008-2010, the world community developed the format of the G-20 for the implementation of joint measures to overcome the recession, and the theory of networkization of world politics became very popular in the foreign humanitaristics. The most prominent apologists of the networkization concept are J. Modelski and E.-M. Slaughter (2012).

The research works of Bogaturov A.D. (2010, 2004), Sulakshin S.S. (2016), and Ponomareva E.G. (2011) cover the modern model of international relations.

The research is based on the institutionalist's method.

\section{Research results}

The unipolar world order that the United States provides is due to the stable maintenance of its overwhelming leadership in four key areas: military-technological, financial-economic, geopolitical and information-ideological.

The bipolar system of international relations was based on the parity of the potentials of the Soviet Union and the United States in the military-industrial complex. After the disintegration of the USSR, Russia, as the sole continuer, retained the right to possess an arsenal of strategic nuclear weapons (including nuclear arsenals exported from the territory of Belarus, Kazakhstan and Ukraine). Due to this, it is appropriate to talk about maintaining parity between Russia and the United States, but only in strategic armaments (taking into account their reductions in mutual obligations under the START treaty). A number of scientists describe the situation as a residual bipolarity (Bogaturov, 2004).

The remaining seven countries (the UK, France, China, India, Pakistan, Israel and the DPRK) possess nuclear weapons, but their reserves allow them only deter nuclear attacks, but not compete with either the US or Russia (Sipri, 2012).

As for the remaining components of the military-industrial complex, since the collapse of bipolarity, the US has gained overwhelming superiority over all other countries of the world in conventional arms, military technologies and control systems. In 2011, the US military budget was 5 times bigger the military budget of China and 10 times bigger the military budget of Russia.

The attempts of the US to consolidate its hegemony in the world, presented in the form of 'leadership', have led to the erosion of international legal principles enshrined in the UN Charter.

The concepts of 'humanitarian intervention' and 'spreading democracy' were brought to the forefront. In practice, Western European countries have demonstrated their readiness to judge the solutions of domestic political disputes in other countries of the world, especially when it comes to geopolitically important countries. A series of 'colour revolutions' have become a demonstration of this policy. In this situation, the authority of the political role of the UN as an organization and the international legal principles it is based on is dropping. The most important of these principles is the sovereignty of states - the cornerstone of world politics since the middle of the 17th century.

After the dissolution of the USSR and the socialist camp with the subsequent collapse of the bipolar system of international relations, Russia's sphere of influence in the world began to rapidly reduce. The Soviet Union actively expanded the allied network around the world, primarily due to powerful ideological (communist and socialist alternative, political support), financial (credits, arms transfers, trade ties within the CMEA, etc.) and intangible (education, cultural cooperation, etc.) resources and incentives. Russia tried to solve a fundamentally different task - to retain the Soviet foreign inheritance under the conditions of an influence shortage. Russia could not cope with this task, even in the regions of vital interests of the country. As a result, Russia's foreign presence is limited to certain former Soviet republics (Belarus, Armenia, partially Azerbaijan, Kyrgyzstan, Tajikistan, Kazakhstan, Uzbekistan, and regions involved in conflicts - Transdniester, South Ossetia and Abkhazia, Ukraine). As for far-abroad countries, only Syria, Serbia and Venezuela are quite loyal to Russia influence.

At the same time, the United States over the past 20 years has not only preserved, but also significantly increased its military presence in the world. 
The current unipolarity model demonstrates certain signs of the coming global restructuring. All prerequisites for the transformation of the world order can be divided into three groups.

The first group: increasing the resistance of some countries or groups of countries to rules, institutions and regulatory mechanisms within a unipolar world order. In this regard, China is the biggest threat to American hegemony. In the last 15 years China has accumulated considerable resources and potential and developed its own tactics of influencing counterparties with the aim of building an allied network. Thus, it has managed to convert its increased economic opportunities into political influence in many countries in Africa, Latin America, Mongolia, etc. The Chinese leadership does not allow American capital to enter its strategic industries and major companies. Despite serious international pressure, China is not going to give up protectionist measures in the interests of national producers and the undervalued exchange rate of its national currency - the renminbi (yuan). Moreover, the Chinese leadership openly promotes the decline of the US dollar in world trade in favour of other currencies and the revision of management rules and quoting in international financial institutions - the International Monetary Fund and the World Bank.

In recent years Latin America has become another significant area of resistance to the Americancentric model of the world order. Since 2010, four states of the Bolivarian alternative (Venezuela, Cuba, Nicaragua and Ecuador) have agreed to replace the US dollars with the virtual currency equivalent (the sucres) for trade payments among themselves. In 2010, after the adoption of the Customs Code, the stage of formation of the customs union of Mercosur's member countries was completed. The organization has started creating conditions for the transition to a new currency union, Argentina and Brazil have already managed to test a number of mutual trade settlements in a single currency. In addition, the Mercosur's countries have reduced their dependence on trade with the United States (an average of 18\%), increasing intra-continental trade.

Being the traditional hotbeds of anti-Americanism, Iran, North Korea and partially Belarus have highlevels resistance to American hegemony. A large potential for resistance to the established rules of the world order is shown by such regional integration blocs such as the Association of Southeast Asian Nations (ASEAN), the Shanghai Cooperation Organization (SCO) and organizations such the CIS operated in the post-Soviet space (CSTO and others). These organisations develop new alternative models of trade, economic and military-political relations among the member countries.

A relatively new phenomenon following the process of increasing the resistance of American hegemony can be considered an accelerated growth of 'grey zones' (Baluev, Novoselov, 2010). The most vivid examples of 'grey zones' are the acts of rebel and terrorist groups that de facto control over or destabilize certain countries (Colombia, Somalia, Iraq) or even regions (East and Central Africa, the Gaza Strip, areas with compact Kurdish population, etc.).

Another field of activity of non-state actors of international relations in the 'grey zones' is the production and distribution of drugs. This process has a particular importance in Central and SouthEast Asia. In these regions, the drug trade has become a strategic industry and an engine of economic development of entire countries. After the collapse of the Soviet Union, the largest drug trafficking corridor from Afghanistan (primarily heroin) to Russia, the United States, Eastern and Western Europe appeared in Central Asia. By 2011, the world drug turnover exceeded 500 billion US dollars (more than $1.5 \%$ of world GDP), and the number of people taking drugs reached 210 million people (4.8\% of the world population) (Sulakshin, 2016).

There are several factors activating the growth of 'grey zones', where drug cartels operate globally. Firstly, despite the decline in the production of drugs from natural raw materials, synthetic drugs are becoming increasingly popular. The infrastructure of their production is not tied to planted areas, which greatly complicates the fight against drug dealing. Secondly, the drug production and distribution industry has one of the most extensive and influential networks of lobbyists around the world. Widespread drug legalization in western countries and the relatively little funding allocated by states for comprehensive drug abuse prevention prove this fact. In 2012, the US Pentagon's anti-drug program received only 109.5 million US dollars. At the same time, U.S. military expenditure in Central Asia amounted to more than 1.31 billion US dollars. The defense budget is used for building military bases, border outposts, and national combat training centers in Central Asia where a lot of military events are being conducted. In general, in 2012 the Pentagon spent about 88.5 billion US 
dollars for conduct of military operations outside the US. During the American occupation of Afghanistan, opiate production in this country increased 15 times. The Taliban has already formally accused the US authorities of growing opium production (Shveic, 2012).

The second group of prerequisites for the transformation of a unipolar world order include factors stipulated by the ineffective performance of US global regulatory functions. The wave of democratization in the early 1990s was officially called upon to bring 'peace and justice'. The democratization strategy was first publicly proclaimed as one of the key sources of American leadership support by the US President Bill Clinton during his annual message to Congress in 1994: 'Ultimately, the best strategy to ensure our security and to build a durable peace is to support the advance of democracy elsewhere'.

In the meantime, over the past 20 years the world has not undergone fundamental changes in the field of reducing conflict. Despite a more than twofold reduction of interstate military conflicts, the number of intra-state conflicts has practically reached the level of the last years of the Cold war, when the bipolar model of the world order was actively dissolving. There was no significant reduction in mortality due to military conflicts (Sipri, 2012).

As for the construction of a viable world order, it has been significantly undermined in such a direction as the global distribution of income. From 1990 to 2010, the gap between developed and developing countries in terms of GDP per capita has not been narrowed.

At the same time, in the world has appeared a group of countries (mainly in Africa and Asia) which have stagnated for more than 20 years.

In recent years, the dynamics of the increasing frequency of crisis phenomena in the world economy is becoming more and more evident, which also leads to the weakening of the globally-regulating functions of the United States.

The third group of prerequisites for the transformation of the unipolar world order includes subjective factors of a decline of the US potential as a world leader. The acute generation crisis and a problem of the US leadership elite succession can be used as a vivid example. In conditions of tough global competition and bipolar confrontation, the American elite have faced two main goals: preventing a nuclear war between the Soviet Union and the United States and containing 'totalitarian ideologies'.

In the 1990s due to the changed goals of global governance and to control international processes, the elite's mindset transformation was required, which in reality turned out to be extremely inert and not ready for new challenges. New leaders were not able to reach the right scale that was the result of widespread mass consumption and consumer culture and the erosion of religious and civilizational values in the West (Minakova, Kovarda, 2015).

\section{Conclusion}

Therefore, the globalization of the modern world does not mean the homogenization of development indicators of countries, but instead leads to further delamination and inequality. The gap between the world leaders and the rest of the world in terms of indicators reflecting the dynamics of the standard of living, the quality of life, scientific and technological progress, after the collapse of the Soviet Union, has significantly increased.

Current global security threats and problems require a solution based on the principle of multilateralism. The proliferation of WMD, terrorism, conflicts on racial, religious, ethnic grounds, the desire to review state borders and territorial disputes, ecological and humanitarian disasters, climate change, mass migration put all participants of world politics in front of the need to establish dialogue, cooperation, search for compromise and joint solutions. No matter how powerful a country is, it is not able to respond to new challenges alone. Therefore, the United States attempts to solve the problems in Iraq and Afghanistan unilaterally has failed. Besides traditional thermonuclear, demographic, energy and environmental threats the modern international system faces another problem - the unity of the world as an integral geopolitical category. The decision-making process in the security sector requires the search, establishment and deepening of new contacts. The system of consolidated coordination and management of the global process requires serious changes. They can be aimed both at the transformation of existing international structures (primarily the $\mathrm{UN}$ ), which requires a compromise between the West and non-Western countries, and at the creation of new organizations without participation of the West. 


\section{References}

Baluev D., Novoselov A. (2010). The «grey zones» of world politics. Essay on current politics, issue, 3.

Bogaturov A.D. (2004) Ponyatie mirovoj politiki v teoreticheskom diskurse [The Notion of «World Politics» in Theorizing International Relations ] . Moscow: International processes, 1 (4), 16-33.

Bogaturov A.D. (2003) Mezhdunarodnyy poryadok v nastupivshem veke [International Order at the Turn of the XXI Century]. Moscow: International processes, 1. Retrieved from URL: www. intertrends.ru/one/001.htm.

Brzezinski Zb. (2009). The Group of Two that could change the world. Financial Times. January. Retrieved from URL: http://www.ft.com/cms/s/0/d99369b8-e178-11dd-afa0-0000779fd2ac.html?nclick_check=1.

Sulakshin S.S. (2016) Rossiya i mir. Rossiyskiy mirovoy proyekt [Russia and the World. Russian World Order]. Retrieved from http://www. bfm.ru/news/2010/11/22/fskn-mirovoj-godovoj-oborot-narkotikov-sostavil-500-mlrd. Html.

Shveic M. (2012). Novyy mirovoy narkoporyadok [The new order in drug world] Retrieved from http://www. Rosbalt.ru/main/2012/03/19/959078.html.

Armaments disarmaments and international security (2012). Retrieved from https://www.sipri.org/sites/default/files/201603/SIPRIYB12Summary.pdf

1994 State Of The Union Address. (1994). Retrieved from http://www. washingtonpost. com/wpsrv/politics/special/states/docs/sou94.htm.

Huntington S. (1999). The Lonely Superpower. Foreign Affairs. March/April.

Huntington S., Samuel P. (1993) The Clash of Civilizations? Foreign Affairs, 3.

Kegley Ch.W., Raymond G. (1994) A Multipolar Peace? Great-Power Politics in the Twenty-First Century. N.Y., 1994.

Kissinger H. (2009) The Chance for a New World Order. The New York Times. January 12.

Kissinger, Henry A. (2011) How to exit Afghanistan without creating wider conflict. The Washington Post. June. Retrieved from URL: http://www.washingtonpost.com/opinions/how-to-exit-afghanistan-withoutcreating-widerconflict/2011/06/06/AG9ydPLH_story.html.

Minakova I.V., Kovarda V.V. (2015). Novyye yavleniya v mezhdunarodnykh ekonomicheskikh otnosheniyakh [The new phenomena in the international economic relations]. Kursk: Publishing house: University Book closed joint stock company, 46-49.

Ponomareva E.G. (2011) Euroasian versus project new world order. Retrieved from URL: http://www. fondsk.ru/news/2011/10/07/evrazijskij-proekt-versus-novyj-mirovojporjadok.html.

Report on human development of 2013. Eminence of the South: human progress in the diverse world. M.: UN, 160-161.

Slaughter A-M. (2012) A Grand Strategy of Network Centrality in America's path: grand strategy for the next administration, Center for a New American Security (Richard Fontaine and Kristin M. Lord, eds.). May 31.

Waltz K. (2000) Globalization and American Power. The National Interest. Spring.

Waltz K. (1993) The Emerging Structure of International Politics. International Security, 2.

Yakunin V.I., Sulakshin S.S., etc. (2012) Politicheskoye izmereniye mirovykh finansovykh krizisov. [Political dimension of the world financial crises.]. Moscow: Scientific expert, 189-199. 